\title{
A Colorimetric Method for the Determination of Deoxyribonucleic Acid in Adipose Tissue
}

\author{
P. B. Curtis-Prior, T. Hanley* and N. J. Temple \\ The Wellcome Research Laboratories, Langley Court, Beckenham, Kent, BR3 $3 B S$, and Department of Medicine, \\ Guy's Hospital Medical School, London, SEl 9RT
}

\begin{abstract}
A method is described for measuring the deoxyribonucleic acid (DNA) content of small samples of adipose tissue or free fat cells. Lipids and acid-soluble nucleotides are first removed by extraction with a cold diethyl ether - ethanol mixture containing 10 per cent. $m / V$ of trichloroacetic acid. DNA is then measured by hydrolysing the nucleoprotein residue in a 5 per cent. solution of trichloroacetic acid at $90^{\circ} \mathrm{C}$ for $20 \mathrm{~min}$, followed by treatment with $p$-nitrophenylhydrazine and measurement of the hydrazone at $560 \mathrm{~nm}$.

Several aspects of the method have been critically examined in order to determine the optimum conditions. The method is satisfactorily reproducible.
\end{abstract}

The metabolic activity of adipose tissue has been the subject of intensive investigation during the last two decades. Probably the best basis for expressing the metabolic activity of this tissue is in terms of its DNA content and a reliable method for measuring the DNA content of adipose tissue is therefore desirable. However, the high lipid content of this tissue, roughly 80 per cent. of the wet mass, ${ }^{1}$ gives rise to handling difficulties owing to emulsion or micelle formation by lipoproteins. Effective removal of these lipids is essential.

A commonly used technique is that described by Schneider ${ }^{2,3}$ in which, after a preliminary extraction in cold aqueous acid, the tissue is extracted once with cold ethanol, and then several times with a hot diethyl ether - ethanol mixture. This procedure is not only very laborious but has also been suspected of causing degradation of DNA.4,5

Whereas removal of the last traces of phospholipids is of importance when DNA is measured in terms of its organic phosphorus content, ${ }^{6}$ small amounts of phospholipid do not interfere with determinations of DNA in terms of its deoxyribose content. A less laborious technique has been developed that is based on this principle.

The colorimetric method used is that established by Webb and Levy, ${ }^{7}$ with some minor but important modifications.

\section{Reagents}

\section{Experimental}

De-ionised, glass-distilled water was used in all experiments.

Diethyt ether - ethanol mixtures. For the diethyl ether-rich mixture add $25 \mathrm{ml}$ of redistilled ethanol to $75 \mathrm{ml}$ of diethyl ether (reagent grade) and mix thoroughly. For the ethanol-rich mixture, use $75 \mathrm{ml}$ of ethanol and $25 \mathrm{ml}$ of diethyl ether.

Extraction mixtures containing trichloroacetic acid. For the diethyl ether - ethanol solutions of trichloroacetic acid, dissolve $10 \mathrm{~g}$ of trichloroacetic acid (analytical-reagent grade) in $100 \mathrm{ml}$ of organic solvent mixture. For the aqueous extraction mixture, dissolve $5 \mathrm{~g}$ of trichloroacetic acid in $100 \mathrm{ml}$ of water.

p-Nitrophenylhydrazine colour reagent. Dissolve $20 \mathrm{mg}$ of $p$-nitrophenylhydrazine (generalpurpose reagent grade) in $2 \mathrm{ml}$ of ethanol with gentle warming.

$n$-Butyl acetate. Use general-purpose reagent grade.

$D N A$ standard solutions. Prepare a stock solution of DNA by adding $50 \mathrm{ml}$ of a 5 per cent. $m / V$ aqueous solution of trichloroacetic acid to $25 \mathrm{mg}$ of salmon-sperm DNA (the purified form of the free acid) in a calibrated flask fitted with an air condenser. Heat on a boiling water bath for $60 \mathrm{~min}$ (see Note). Allow to cool to room temperature, add water to replace the small amount lost by evaporation, mix well and store at $4{ }^{\circ} \mathrm{C}$. Prepare, fresh

\footnotetext{
* Present address: Department of Geriatric Medicine, University Hospital of South Manchester, Manchester, M20 8LR.
} 
daily, standard solutions containing 20,10 and $5 \mu \mathrm{g} \mathrm{ml}^{-1}$ of DNA, by diluting the stock solution of DNA with 5 per cent. $m / V$ aqueous trichloroacetic acid solution.

By using these standard DNA solutions, the following equation relating DNA concentration in micrograms per millilitre $(x)$ and absorbance at $560 \mathrm{~nm}(y)$ was derived: $y=0.02533 x$.

NOTE-

When samples of 2 -deoxy-D-ribose dissolved in 5 per cent. $m / V$ trichloroacetic acid were incubated, as described for DNA standard solutions, for 30 or $60 \mathrm{~min}$, there was no significant difference, as measured by this $p$-nitrophenylhydrazine method, between the results obtained for the incubated samples and a non-incubated control. Incubation of DNA for $30 \mathrm{~min}$ in aqueous 5 per cent. $m / V$ trichloroacetic acid was the mode of preparation of standard solutions used in the original method established by Webb and Levy." Further, the results given under Recovery of DNA suggest that salmon-sperm DNA is not destroyed by heating at $90^{\circ} \mathrm{C}$ for $20 \mathrm{~min}$. It would seem that the hydrolysis separates deoxyribose from nucleoprotein but without degrading the carbohydrate moiety.

\section{Apparatus}

A Hitachi - Perkin-Elmer, Model 139, spectrophotometer and a Model 159 recorder were used for the spectrophotometry.

\section{Removal of Lipid}

\section{Procedure}

We have applied the method to (A) pieces of adipose tissue weighing up to $300 \mathrm{mg}$ and (B) suspensions of isolated fat cells prepared by a modification,,$^{8,9}$ of the technique of Rodbell, ${ }^{10}$

(A). To a known mass of fresh adipose tissue $(50$ to $300 \mathrm{mg})$ in a chilled Potter-Elvehjem ${ }^{11}$ homogeniser tube, add $4 \mathrm{ml}$ of the cold diethyl ether - ethanol mixture $(3+1)$ containing 10 per cent. $m / V$ of trichloroacetic acid. Homogenise for $2 \mathrm{~min}$ and transfer to a $15-\mathrm{ml}$ capacity polypropylene centrifuge tube using a further $6 \mathrm{ml}$ of the trichloroacetic acid solution to rinse the homogeniser plunger and tube. Pool the first homogenate and the trichloroacetic acid rinsings, centrifuge for $10 \mathrm{~min}$ at $4000 \mathrm{~g}$ in chilled centrifuge buckets and discard the supernatant fluid. Re-suspend the precipitate in $5 \mathrm{ml}$ of cold diethyl ether - ethanol $(3+1)$, without trichloroacetic acid. Mix well, centrifuge as before, aspirate and discard the supernatant fluid.

(B). Dispense $1-\mathrm{ml}$ portions of a suspension of isolated fat cells (lipid content 20 to $80 \mathrm{mg}$ ) into Potter - Elvehjem tubes, add $4 \mathrm{ml}$ of cold ethanol - diethyl ether mixture $(3+1)$ containing 10 per cent. $\mathrm{m} / \mathrm{V}$ of trichloroacetic acid, homogenise for about $1 \mathrm{~min}$ and proceed as before but re-suspend the precipitate in ethanol - diethyl ether $(3+1)$.

\section{Tissue Hydrolysis}

To the slightly damp protein pellet, add $3 \mathrm{ml}$ of a 5 per cent. $m / V$ aqueous solution of trichloroacetic acid and several anti-bumping granules. Use a glass rod to fragment and disperse the protein, then incubate at $90^{\circ} \mathrm{C}$ in a shaking water-bath for 20 min with frequent and thorough agitation by means of the glass stirring rod. Allow to cool, then centrifuge for $20 \mathrm{~min}$ and retain the maximum possible volume of supernatant. Transfer exactly $2 \mathrm{ml}$ of this supernatant in the case of adipose cells (or $1 \mathrm{ml}$ of supernatant plus $1 \mathrm{ml}$ of aqueous 5 per cent. $m / V$ trichloroacetic acid in the case of fresh adipose tissue samples) or $2 \mathrm{ml}$ of DNA standard solution or aqueous 5 per cent. $m / V$ trichloroacetic acid as "blank," into a glass tube of 12-ml capacity, with a standard ground-glass neck and securing spring hooks.

\section{Hydrazone Formation}

Add $40 \mu \mathrm{l}$ of freshly prepared colour reagent $(20 \mathrm{mg}$ of $p$-nitrophenylhydrazine dissolved in $2 \mathrm{ml}$ of ethanol) to each sample and mix. Equip each tube with a "cold finger" cooled by tap water and secured with springs. Incubate in a boiling water bath for 20 min, then allow to cool.

\section{Removal of Excess of Colour Reagent}

Transfer the whole of each sample to $15-\mathrm{ml}$ centrifuge tubes and add $7 \mathrm{ml}$ of $\mathrm{n}$-butyl acetate. Shake vigorously for $2 \mathrm{~min}$. Centrifuge briefly to separate the phases; aspirate and discard the upper phase. Repeat the washing procedure twice more. 


\section{Spectrophotometric Measurement of the Colour Developed by Alkali}

Transfer $1 \mathrm{ml}$ of the washed lower phase into a $1-\mathrm{ml}$ glass centrifuge tube, spin briefly and aspirate any visible n-butyl acetate, plus the uppermost layer of the aqueous solution. Transfer $500 \mu \mathrm{I}$ of the remaining solution into a glass microcuvette of 2 -cm light path, and add $200 \mu \mathrm{l}$ of fresh, aqueous $4 \mathrm{~N}$ sodium hydroxide solution. Stopper the cuvette or cover it with a glass cover-slip, and mix by repeated inversion. Stirring is inadequate for efficient mixing, owing to the high specific gravity of the alkali relative to the tissue extract. Read the absorbance of the magenta-coloured solution at $560 \mathrm{~nm}$, exactly 3 min after the addition of alkali. Refer the absorbance of unknown solutions to the calibration equation (see above) to determine their DNA concentration.

\section{Investigation of Stages of the Procedure}

\author{
Slage \\ Hydrolysis of DNA \\ Removal of excess of $p$-nitrophenyl- \\ hydrazine \\ Time course of colour development and \\ recession \\ Whole procedure
}

\author{
Aspects investigated \\ Optimum temperature, time and acid concentration \\ Number of n-butyl acetate washes \\ Optimum time for reading colorimetric change. Influence \\ of $\mathrm{pH}$ \\ Reproducibility. Recovery of DNA
}

\section{Hot Acid Hydrolysis of DNA}

Schneider, ${ }^{2,3}$ employing the diphenylamine reaction, ${ }^{12}$ determined the optimum conditions for hot acid hydrolysis of liver nucleoproteins to be $90{ }^{\circ} \mathrm{C}$ for $15 \mathrm{~min}$ with 5 per cent. $\mathrm{m} / \mathrm{V}$ trichloroacetic acid, but Webb and Levy ${ }^{7}$ suggested a longer incubation. We performed three experiments (all using a mass of macerated rat epididymal adipose tissue as starting material) in which one variable was changed at a time. In the first series, incubation was effected for 20 min using 5 per cent. $m / V$ trichloroacetic acid at five temperatures between 80 and $100^{\circ} \mathrm{C}$. In the second experiment, the temperature was maintained at $90^{\circ} \mathrm{C}$ and the trichloroacetic acid concentration at 5 per cent. $m / V$, but the time of incubation was varied from 5 to $60 \mathrm{~min}$. Finally, we examined the influence of different trichloroacetic acid concentrations.

The results in Table $I$ led us to adopt $90^{\circ} \mathrm{C}$ as the temperature of incubation, $20 \mathrm{~min}$ as the time and 5 per cent. $m / V$ as the concentration of trichloroacetic acid for our standard procedure.

\section{TABLE I}

CONDITIONS FOR HOT ACID HYDROLYSIS OF RAT ADIPOSE TISSUE NUCLEOPROTEIN

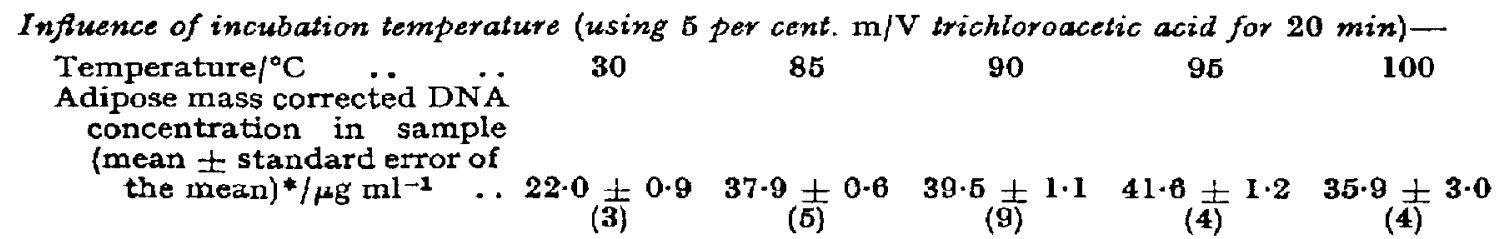

Influence of the time of incubation (at $90^{\circ} \mathrm{C}$ using 5 per cent. $\mathrm{m} / \mathrm{V}$ trichloroacetic acid)-

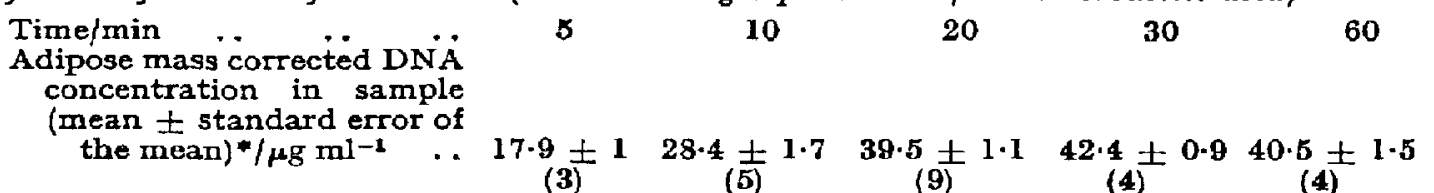
(3)
(5)
(9)
(4)
(4)

Influence of trichloroacetic acid concentration (at $90^{\circ} \mathrm{C}$ for 20 min) -

Trichloroacetic acid concentration, per cent. $m / V$.

Adipose mass corrected DN $A$

10

20

40

concentration in sample

(mean $t$ standard error of the mean $)^{*} / \mu \mathrm{g} \mathrm{ml}^{-1} \quad \ldots \quad 34.9$

(3)

0.3 $\quad 39-5$

(9) (4)

(4) $\quad(4)$

(4) $\left(\frac{1}{4)}\right.$

$33 \cdot 7+1 \cdot 4$

- Figures in parentheses indicate number of observations. 


\section{Removal of Excess of p-Nitrophenylhydrazine Colour Reagent}

After hydrazone formation with the deoxyribose is complete, any excess of $p$-nitrophenylhydrazine must be removed, or it will itself form a coloured complex on addition of alkali. In the original technique by Webb and Levy ${ }^{7}$ a single wash with n-butyl acetate is recommended, but we found this to be inadequate if consistently low blank values were to be obtained (an important factor if only small amounts of DNA are present in the sample). The absorbance of blanks treated with a single $7-\mathrm{ml}$ wash of n-butyl acetate was $0.135 \pm 0.003$ (mean \pm standard error of the mean, number of readings $=8$ ), whereas the value for the thrice-washed sample was $0.018 \pm 0.0004$.

In the preparation of standard curves for DNA, erratic and non-linear standard calibration lines were obtained when only one wash with n-butyl acetate was used. More prolonged shaking or an increase of the single-wash volume to $10 \mathrm{ml}$ produced little improvement.

\section{Development of Colour by Alkali}

The absorbance of replicate samples of a standard DNA solution was measured 3 min after addition of alkali of various concentrations, and the rate' of fall in absorbance was also recorded.

Volumes of $200 \mathrm{ml}$ of $1,2,3,4$ or $8 \mathrm{~N}$ sodium hydroxide solution were added to replicate samples of a DNA solution. There was an almost immediate development of maximal colour that was unrelated to the alkali concentration provided that the $\mathrm{pH}$ was 11 or higher. ${ }^{7}$ The fall in absorbance was almost linear during the period of examination (about 20 min after the addition of alkali) at approximately 1 per cent. min-1. The rate of colour loss was not related to the concentration of alkali present.

\section{Reproducibility of the Complete Procedure}

Ten replicate samples of macerated rabbit perineal adipose tissue, each weighing approximately $300 \mathrm{mg}$, were found to have a DNA content of $94 \cdot 2 \pm 2 \cdot 3 \mu \mathrm{g} \mathrm{g}^{-1}$ of fresh tissue; the coefficient of variation was $5 \cdot 4$ per cent. and the standard error was $5 \cdot 1$ per cent.

In another experiment, a homogenate of rat epididymal adipose tissue provided three batches of sample weighing 100,200 or $300 \mathrm{mg}$. The results shown in Fig. 1 indicate good reproducibility at all three levels of sample size.

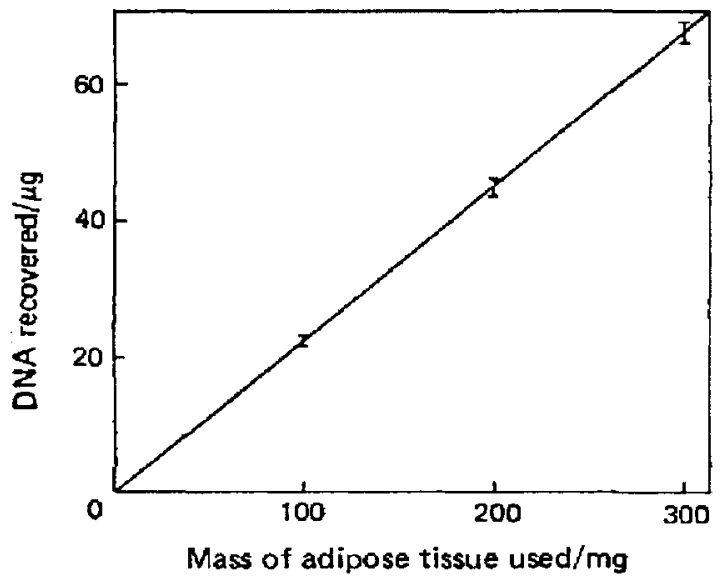

Fig. 1. Relationship between DNA recovered and mass of adipose tissue sample. Each point represents the mean of seven replicate observations \pm the standard error of the mean.

\section{Recovery of DNA}

In a final test of the method a "recovery" experiment was carried out on samples prepared from a large mass of adipose tissue. The DNA concentration, measured for five samples of about $600 \mathrm{mg}$, was $362 \cdot 2 \mu \mathrm{g} \mathrm{g}^{-1}$. Four other samples of mean wet mass $579 \mathrm{mg}$ and calculated 
total DNA content $208.4 \mu \mathrm{g}$ were de-fatted, and to the protein pellets were added $317 \mu \mathrm{g}$ of purified salmon-sperm DNA. The total DNA content was then measured by continuing the analytical procedure from this stage.

The expected mean total DNA content of the sample and added DNA was $525 \cdot 4 \mu g$ $(208 \cdot 4+317 \mu \mathrm{g})$, and the mean total as found colorimetrically was $520 \cdot 7 \mu \mathrm{g}$. The mean "recovery" was thus 98.8 per cent. (standard error of the mean, 1.6 per cent.). This result indicates a negligible loss, and acceptable precision, from the protein-pellet stage of the analysis onwards.

\section{Discussion}

If DNA is determined by measuring the organic phosphorus content of tissues it is necessary to remove thoroughly lipids that contain phosphorus, and this is accomplished by using the elaborate and time-consuming Schneider procedure. It is not necessary to remove lipids when DNA is determined in terms of its deoxyribose content. Lipid extraction is, however, still necessary with adipose tissue for the different purpose of preventing the emulsion and micelle formation that occur in homogenised adipose tissue. The much simpler extraction described here seems adequate for lipid removal; no difficulty with emulsion formation was encountered after the extraction.

After the stage of colour development, any excess of $p$-nitrophenylhydrazine must be removed, as this will itself increase absorbance at $560 \mathrm{~nm}$, in the presence of alkali. Webb and Levy recommended a single wash with n-butyl acetate, but however well done, this single wash gave blank values of about 0.135 absorbance unit and this was unacceptably high when absorbances of from 0.01 to 0.4 were recorded from DNA itself.

It was found that if the blank value were to be reduced to about $0 \cdot 01$, three successive washes with $7 \mathrm{ml}$ of $\mathrm{n}$-butyl acetate were required. This added to the labour and time of the analysis, but is worthwhile because of the increased sensitivity achieved. Although the $n$-butyl acetate wash was originally designed to remove excess of colour reagent and trichloroacetic acid was said to be necessary to effect quantitative extraction, it is of interest that Young ${ }^{13}$ reported the use of $n$-butyl acetate as a solvent for the extraction of trichloroacetic acid. As one extraction with an equal volume of n-butyl acetate gives 80 per cent. removal of trichloroacetic acid, the amount of trichloroacetic acid in solution during our second and third washes with $\mathrm{n}$-butyl acetate must assume negligible proportions. A systematic investigation of the use of trichloroacetic acid saturated n-butyl acetate might, therefore, prove of value in reducing the number of washes. It is of interest that in another modification of this technique ${ }^{14}$ excess of colour reagent is removed by reaction with acetyl acetone and the chromophore extracted into butanol.

The colorimetric test used by Schneider for the determination of DNA in the final tissue extract was either the carbazole ${ }^{15}$ reaction or the diphenylamine reaction of Dische. ${ }^{12}$ The carbazole reaction is not specific for carbohydrates ${ }^{\mathbf{1 0}}$ and the unmodified diphenylamine reaction is far less sensitive than the $p$-nitrophenylhydrazine reaction. Further, the protocol described has been used to measure DNA in 20-50 samples during the working day, whereas the modified diphenylamine reactions of Burton $^{17}$ or Ganguli ${ }^{18}$ involve a $17-\mathrm{h}$ incubation period. However, the recently published method of Abraham et al., 19 which is an improvement of the technique of Giles and Myer's modification ${ }^{20}$ of the diphenylamine reaction, would appear to be a very convenient method for the determination of low concentrations of standard DNA solutions although its validity for biological samples remains unproved.

We acknowledge with thanks the encouragement of Professor W. J. H. Butterfield, the valuable statistical help of Mr. F. W. Harpley and Mr. D. A. Field and the technical assistance of Mr. T. Kelly. We are grateful to Dr. R. H. Nimmo-Smith for his gift of the purified salmon-sperm DNA used as standards.

\section{References}

1. Boshart, C. R., Will, L., and Pirre, A., Proc. Soc. Exp. Biol. Med., 1962, $110,661$.

2. Schneider, W. C., J. Biol. Chem., 1945, 161, 293.

3. Schneider, W. C., Methods Enzym., 1957, 3, 680.

4. Munro, H. N., and Fleck, A., Analyst, 1966, 91, 78.

5. Hutchinson, W. C., Downie, E. D., and Munro, H. N., Biochim. Biophys. Acta, 1962, 55, 561. 
6. Schmidt, G., and Thannhauser, S. I. J. Biol. Chem., 1945, 161, 83

7. Webb, J. M., and Levy, H. B., J. Biol. Chem., 1955, 213, 107.

8. Curtis-Prior, P. B., Guty's Hosp. Rep., 1972, 121, 167.

9. Curtis-Prior, P. B.. and Hanley, T., Acta Endocr. Copenh., 1973, 14, 409.

10. Rodbell, M., J. Biol. Chem., 1964, 239, 375.

11. Potter, V. R., and Elvehjem, C. A., J. Biol. Chem., 1936, 114, 495.

12. Dische, $Z$., Mikrachemie, $1930,8,9$.

13. Young, D. A. B., Biochim. Biophys. Acta, 1964, 90, 178

14. Martin, R. F., Donohue, D. C., and Finch, L. R., A nalyt. Biochem., 1972, 47, 662.

15. Gurin, S., and Hood, D. B., J. Biol. Chem., 1941, 139, 775.

16. Hutchison, W. C., and Munro, H. N., Analyst, 1961, 86, 768.

17. Burton, K., Biochem. $J ., 1956,62,315$.

18. Ganguli, P. K., Revue Can. Biol., 1970, 29, 339.

19. Abraham, G. N., Scaletta, C., and Vaughan, J. H., Analyt. Biochem., 1972, 49, 547.

20. Giles, K. W., and Myers, A., Nature, Lond., 1965, 206, 93. 